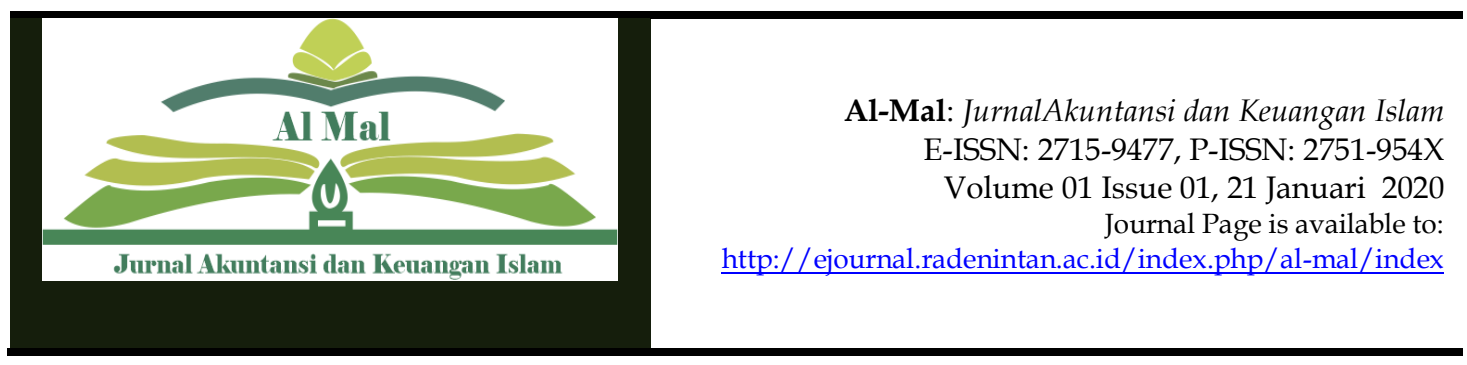

\title{
Kinerja Pembiayaan Perbankan Syariah: Indikasi Moral
}

\section{Hazard}

\author{
Hilmi Baroroh ${ }^{*}$ \\ 1* Departement of Economics, Faculty Economic and Bussines Islamic, \\ Universitas Islam Negeri Sunan Kalijaga, Indonesia
}

\begin{tabular}{l}
\hline \multicolumn{1}{c}{ ARTICLE INFO } \\
\hline Article history: \\
Received 18-01-2020 \\
Revised 18-01-2020 \\
Accepted 18-01-2020 \\
Available 21-01-2020 \\
Revised (1) 16-05-2022 \\
Revised (2) 11-07-2022 \\
Accepted 11-07-2022 \\
Revised Available 17-07-2022 \\
\hline Kata Kunci: \\
Kinerja Pembiayaan, Moral Hazard, \\
NPF, GDP
\end{tabular}

Paper type: Research paper

Please cite this article: Baroroh, $\mathrm{H}$.

"Kinerja Pembiayaan Perbankan Syariah: Indikasi Moral Hazard" AlMal: Jurnal Akuntansi dan Keuangan Islam [ONLINE], Volume 02 Number 01 (Januari 21, 2020)

\section{Cite this document:}

Al-Mal 2th edition

\section{*Corresponding author} e-mail:Hilmy.baroroh@uinsukka.ac.id

\begin{abstract}
ABSTRAK
Penelitian ini bertujuan untuk menganalisis indikasi moral hazard dengan melakukan uji pengaruh pada kinerja pembiayaan perbankan syariah dengan indikator kredit macet atau NPF. Studi kasus pada perbankan syariah periode 2010-2015 dengan menggunakan metode ECM untuk mengetahui pengaruh jangka panjang dan jangka pendek suatu variabel. Hasil dari penelitian ini menunjukkan bahwa GDP dalam jangka panjang berpengaruh positif terhadap kredit macet sehingga hal ini berindikasi adanya moral hazard. Namun, inflasi dan rasio margin terhadap bagi hasil tidak berpengaruh terhadap NPF. Selain itu, pada FDR dan rasio alokasi pembiayaan dalam jangka pendek maupun jangka panjang tidak terdapat indikasi moral hazard. Keterabatasan pada penelitian ini terletak pada varaibel yang mempengaruhi moral hazard dipengaruhi oleh variabel kinerja pembiayaan perbankan syari'ah sehingga membuka peluang bagi peneliti-peneliti lainnya untuk melakukan penelitian lebih mendalam berkaitan dengan indikasi moral hazard. Implikasi penelitian yaitu untuk menambah khasanah ilmu pengetahuan berkaitan dengan indikasi moral hazard yang bisa terjadi ketika adanya kinerja pembiayaan perbankan syariah yang buruk.
\end{abstract}

Al-Mal with CC BY license. Copyright (C 2020, the author(s) 


\begin{abstract}
This study aims to analyze the indications of moral hazard by testing the effect on the performance of Islamic banking financing with bad credit or NPF indicators. A case study on Islamic banking for the 2010-2015 period using the ECM method to determine the long-term and short-term effects of a variable. The results of this study indicate that GDP in the long term has a positive effect on bad loans, so this indicates a moral hazard. However, inflation and the ratio of margin to profit sharing have no effect on NPF. In addition, there is no indication of moral hazard in the FDR and the ratio of financing allocation in the short and long term. The limitation of this study lies in the variables that affect moral hazard, which are influenced by the performance variable of Islamic banking financing, thus opening up opportunities for other researchers to conduct more in-depth research related to indications of moral hazard. The implication of the research is to add to the repertoire of knowledge related to indications of moral hazard that can occur when there is poor performance in Islamic banking financing.
\end{abstract}

\title{
Keywords : Financing Performance, Moral Hazard, NPF, GDP
}

\section{INTRODUCTION}

Krisis keuangan yang terjadi pada tahun 1997 memunculkan kebijakan kredit yang kurang berhati-hati. Penjaminan yang diberikan oleh IMF untuk negara berkembang yang mengalami krisis menjadikan bank sentral justru semakin berani mengambil risiko dalam memberikan pinjaman. Setelah krisis moneter yang melanda Indonesia di akhir dekade 90-an, pembiayaan bermasalah perbankan konvensional semakin membaik seperti yang ditunjukkan oleh nilai NPL yang senantiasa menurun. Sedangkan pembiayaan bermasalah untuk bank syariah juga menunjukkan tren yang stabil pada skala 2-4 persen (Muhammad Iqbal, 2017).

Hal tersebut di atas menjadi faktor yang memperburuk kondisi ekonomi. Kebijakan kredit bank dinilai kurang berhati-hati, sementara 
back up system yang disediakan bank sentral justru membuat bank semakin berani mengambil risiko dalam memberikan pinjaman (Morris, 
1998). Kondisi kebangkrutan dan kerugian tersebut, tentunya memberikan dampak yang cukup mengkawatirkan dalam industri perbankan di seluruh dunia, tidak terkecuali industri perbankan syariah di Indonesia (Heri Pratikto \& Iis Sugianto, 2017:109). Dampak yang ditimbulkan dari krisis ini berupa nilai hutang perusahaan yang semakin pesat, selanjutnya akan menyebabkan banyak perbankan mengalami kebangkrutan, namun bank muamalat sebagai satusatunya bank yang menerapkan sistem syariah pada waktu itu ternyata bisa bertahan (Kurnia Sari Kasmiarno \& Karjadi Mintaroem, 2016:816).

Kinerja keuangan adalah gambaran kondisi keuangan perusahan pada suatu periode tertentu baik menyangkut aspek penghimpunan dana manapun penyaluran dana, yang biasanya diukur dalam indikator kecukupan modal, likuiditas, dan profitabilitas (Elvira Luthan dkk, 2017). Persaingan antar perbankan dalam meningkatkan kualitas pelayanan untuk menarik nasabahnya juga semakin tinggi.

Beragam jasa pelayanan yang diberikan oleh bank juga mengalami perkembangan (Yudhistira Ardana \& Wulandari, 2018). Perbankan syariah memiliki potensi yang sangat besar dalam perekonomian. Sistem perbankan syariah ini sangat cocok untuk mengembangkan UMKM yang memiliki peran strategis dalam menggerakkan pembangunan ekonomi nasional (Mohammad Rizal dkk, 2020). Salah satu indikator dalam mengalokasikan dana adalah seberapa besar pembiayaan yang disalurkan oleh bank kepada nasabah, penyaluran dana yang dilakukan oleh bank adalah antara lain, pembiayaan jual beli, bagi hasil, dan sewa (Celine Quatro dkk, 2021).

Dalam banyak riset, era syariah telah menarik minat ekonom dunia, bahkan banyak negara-negara maju di Eropa dan Amerika sebagian unit usahanya telah beralih ke model syariah. Mengingat kekuatan pada sistem syariah ada pada konsep fundamental, yakni 
mengedepankan hak dan keuntungan konsumen ketimbang keuntungan perusahaan (Fitri Sagantha, 2020). Namun, dalam mekanisme tersebut banyak peminjam dana yang mengalami kredit macet akibat tingginya tingkat suku bunga yang ditetapkan oleh bank sentral Amerika Serikat, sehingga menyebabkan lembaga keuangan dan penjamin simpanan menderita kerugian (Heri Pratikto \& Iis Sugianto, 2017).

Istilah moral hazard ini berkembang ke seluruh bidang salah satunya di sistem perbankan. Hal ini terjadi ketika semua deposito dijamin oleh penjamin bank saat terjadi kebangkrutan, ini dapat memicu deposan untuk menitipkan hartanya di bank-bank kecil yang menawarkan suku bunga lebih tinggi. Bank syariah tidak menggunakan bunga sebagai alat untuk memperoleh pendapatan maupun membebankan bunga atas penggunaan dana dan pinjaman, namun sebagai gantinya diterapkan pola bagi hasil (Adi Susilo Jahja \& Muhammad Iqbal, 2012). Bank-bank swasta merasa aman karena Bank Indonesia bersedia memberikan jaminan ketika terjadi pelanggaran prudential requirements yang sewaktu-waktu terjadi. Pada akhirnya bankbank swasta akad nekad, jaminan dari bank sentral akan disalahgunakan karena adanya ketidakjujuran dari pemilik bank atau pengurusnya. Sementara, di sisi lain hal ini juga merugikan bank-bank besar yang tidak mau memberikan suku bunga tinggi.

Akibatnya seluruh elemen perekonomian harus ikut menanggung dampak dari kondisi ini dan pada akhirnya akan menimbulkan inflasi (Ibrahim dan Ragimun, 2010). Tingginya risiko pembiayaan (dan atau lemahnya absorpsi sektor riil) akan menyebabkan perbankan syariah bisa mengurangi penyaluran dana ke sektor riil. Pemindahan portofolio ke dalam PUAS dan SWBI merupakan cerminan dari sifat bisnis perbankan syariah di Indonesia yang masih risk averse (Saekhu, 2015:105). Perbankan syariah adalah salah satu representasi 
aplikasi dari ekonomi Islam yang melarang penggunaan sistem bunga dalam perekonomian khususnya perbankan, karena sistem tersebut dianggap riba yang dilarang oleh agama (Mohammad Taufik Azis, 2018).

Mengacu pada pernyataan tersebut, ketidakhati-hatian bank dalam menyalurkan dana pihak ketiga dapat dikategorikan moral hazard. Kita juga dapat menganalisis sejumlah kasus yang ditemukan di perbankan konvensional seperti yang terjadi di Bank Mandiri yang mengalami kredit macet sebesar 2,7 triliun dan adanya bank persyarikatan dalam kategori bank dalam pengawasan khusus dari sudut moral hazard (Nasution dan Wiliasih, 2007).

Sebagaimana hasil penelitian Eicengreen dalam Dreher (2004) terdapat dugaan kuat bahwa masalah sebenarnya terletak pada sistem perbankan dan pendistribusian risiko. Sebenarnya dalam pendistribusian bank syariah menawarkan konsep yang lebih baik dibandingkan dengan bank konvensional. Bank syariah menggunakan sistem profit and loss sharing sebagai pengganti sistem bunga yang merupakan determined return.

Dalam menjalankan kegiatan usahanya bank umum dapat memilih satu dari tiga pilihan yaitu seluruhnya beroperasi secara konvensional, seluruhnya beroperasi secara syariah, atau melakukan kegiatan usaha secara konvensional sekaligus juga melakukan kegiatan usaha berdasarkan prinsip syariah dual system bank (Mohammad Taufik Aziz, 2018:4). Untuk menghindari pengoperasian bank dengan sistem bunga, Islam memperkenalkan prinsip-prinsip muamalah Islam. Bank syariah lahir sebagai salah satu solusi alternatif terhadap persoalan pertentangan antara bunga bank dengan riba (Akhmad Sirojudin Munir, 2017:60).

Sistem pendistribusian yang dilakukan oleh bank syariah dengan profit and loss sharing sebagai bentuk akad kongsi yang dipromosikan bank 
syariah ini di satu sisi memang memiliki risiko yang besar yaitu dalam hal kredit macet yang direpresentasikan dalam Non Performing Financing (NPF).Jenis pembiayaan murabahah merupakan lebih memiliki unsur kepastian dibandingkan dengan skema bagi hasil karena penetapan persentase margin keuntungan dikemukakan di awal akad. Hal ini menyebabkan bank dapat memastikan jumlah keuntungan yang akan diperoleh atas aktivitas pembiayaan yang dilakukan (Mirasanti Wahyuni, 2016).

Kredit macet yang terjadi di perbankan syariah secara tidak langsung akan memunculkan banyak asumsi tentang seberapa giat bank syariah dalam memonitoring proses pembiayaan dari awal penyaluran dananya. Jika bank syariah mengedepankan prinsip kehati-hatian dalam proses memilih nasabah yang memiliki capability baik dan slalu memantau setiap kinerja nasabahnya tentunya kenaikan NPF bisa diantisipasi. Kredit bermasalah pada nasabah bisa menjadi akibat adanya perilaku-perilaku menyimpang dari aturan yang dilakukan baik perbankan syariah maupun nasabahnya. Seberapa besar kredit macet yang dialami oleh perbankan syariah mencerminkan seberapa besar pula bank syariah mampu membangun sistem yang optimal untuk kedua belah pihak yaitu nasabah dan bank. Sistem yang optimal ini sendiri menjadi kunci agar terhindar dari penyimpangan-penyimpangan yang mungkin dapat dilakukan oleh pihak bank dan nasabah. Oleh sebab itu peningkatan atau penurunan NPF menjadi cerminan seberapa optimalnya sistem operasional yang dirancang oleh perbankan syariah untuk mengantisipasi adanya tindakantindakan moral hazard. Pembiayaan syariah sendiri memiliki definisi sebagai suatu kegiatan yang menyediakan uang dan tagihan atas dasar kesepakatan antara bank dengan nasabah serta mengharuskan nasabah yang didanai untuk mengembalikan uang atau tagihan tersebut dalam 
jangka waktu tertentu dengan imbalan atau bagi hasil (Devi Permatasari \& Ahmad Rudi Yulianto, 2018:70).

Kinerja perbankan menjadi faktor utama dan sangat penting untuk menilai tingkat kesehatan bank berdasarkan dari penilaian aset, utang, likuiditas dan lain sebagainya. Kinerja suatu bank dapat dinilai dengan melakukan analisis terhadap laporan keuangannya. Berdasarkan laporan keuangan tersebut kemudian dapat dihitung rasio keuangan untuk menilai tingkat kesehatan bank (Arif Nugrihi, 2020:60). Peningkatan pembiayaan seharusnya diikuti oleh suatu prudential practice sehingga tidak terjadi kenaikan NPF. Kebijakan pembiayaan bank syariah yang kurang berhati-hati dapat menyebabkan terjadinya NPF yang berindikasi pada moral hazard. Seperti yang terjadi di tahun 2015, NPF bank syariah mengalami peningkatan. Oleh karena itu, di tahun ini industri perbankan syariah masih dalam proses konsolidasi sebagai dampak dari pembiayaan bermasalah yang terjadi pada 2015 (Ketua Dewan Komisioner OJK Muliaman D Hadad dalam konferensi pers akhir tahun OJK, 2016).

Selain itu, dengan menggunakan sistem bagi hasil dan risiko (profit and loss sharing) bank syariah harus tetap memonitoring alokasi pembiayaannya. Karena hal tersebut merupakan konsekuensi dari prinsip perbankan syariah yang mengedepankan prinsip keadilan dan kebersamaan dalam berusaha, baik dalam memperoleh keuntungan maupun dalam menghadapi risiko.

Dalam alokasi pembiayaan sejauh ini bank syariah masih memiliki persentase yang tinggi pada akad murabahah. Hal ini dikarenakan dalam pembiayaan perbankan syariah sistem bagi hasil kurang diminati oleh masyarakat. Perbankan syariah terkesan kurang ekspansif menyalurkan dana ke sektor riil karena bagi hasil dan risiko ditanggung bank dan nasabah. Seperti pada tabel di bawah ini dapat dilihat bahwa total pembiayaan murabahah sebesar 558,985 miliar rupiah, 
sementara pembiayaan pada akad mudharabah 49,020 miliar rupiah dan musyarakah sebesar 271.643 miliar rupiah.

Pada sisi internal, FDR (Financing to Deposit Ratio) berperan dalam meningkatkan persentase NPF. FDR yang dilakukan secara masif bisa mengakibatkan meningkatnya risiko kredit macet, tetapi bila tingkat FDR rendah maka sektor riil juga tidak akan berkembang (Poetry dan Sanrego, 2011).

Penyaluran kredit merupakan kegiatan utama bank, oleh karena itu sumber pendapatan utama bank berasal dari kegiatan ini. Semakin besar kredit yang disalurkan dibandingkan dengan simpanan masyarakat pada suatu bank membawa konsekuensi semakin besar risiko yang harus ditanggung oleh bank yang bersangkutan. Dengan kata lain semakin besar FDR semakin besar pula rasio NPF (Yasin, 2014). Jika memang tingkat FDR yang semakin tinggi juga mengakibatkan kenaikan NPF maka hal ini berindikasi pula adanya kurangnya sifat prudential practice. Sebab sebagai bank yang berlandaskan nilai moral Islam seharusnya prinsip kehati-hatian didepankan dalam menjalankan operasionalnya.

Selain kondisi internal perbankan syariah, hal lain yang dapat mempengaruh kelancaran suatu usaha adalah kondisi makro suatu negara. Variabel makro suatu negara salah satunya adalah Gross Domestic Product (GDP). GDP adalah salah satu alat untuk mengukur tingkat perekonomian suatu negara. Tingkat GDP ini juga dapat menjadi indikator moral hazard dari sisi makroekonomi. Indikator moral hazard di perbankan syariah ini terjadi jika saat NPF meningkat saat GDP meningkat. Idealnya, ketika GDP meningkat maka terjadi peningkatan transaksi ekonomi, dunia bisnis lebih menggeliat sehingga jika pada kondisi tersebut NPF meningkat mengindikasikan bank kurang berhatihati atau kurang monitoring (Mustofa Edwin, 2007). 
Covitz dan Heitfield (1999) melakukan penelitian untuk melihat hubungan antara kekuatan dengan suku bunga pinjaman dan sekaligus risiko bank yang tidak memberikan sistem pencegahan yang efektif bagi moral hazard dalam hubungan dengan peminjam, dan bank dengan jaminan pemerintah. Hasil penelitian ini mengindikasikan adanya hubungan ketergantungan berdasarkan institusi dari parameter masalah moral hazard yang tumpang tindih. Bank dengan kekuatan pasar yang besar cenderung mengalami masalah moral hazard yang tinggi dengan nasabah dibandingkan sikap moral hazard bank terhadap jaminan pemerintah. Ditemukan juga bahwa tingkat kompetisi antar bank mengakibatkan kondisi makroekonomi yang lebih fluktuatif karena membiarkan dengan mudah terjadinya moral hazard dari sisi nasabah.

Penelitian yang dilakukan oleh Dow (2000) melihat hubungan antara teori struktur modal dan regulasi modal bank, moral hazard, dan teori keagenan pada tingkatan individual trader, financial firm, dan sistem keuangan secara keseluruhan. Peneliti melakukan penelitian tentang systematic risk yang dilihat berdasarkan beberapa penelitian terdahulu dan beberapa studi kasus yang berkaitan dengan kegagalan dan krisis keuangan perusahaan dan masalah moral hazard yang berkaitan dengan systematic risk. Hasil dari penelitian ini menunjukkan bahwa moral hazard dan leverage (hutang) pada level individual firm dapat menyebabkan goncangan yang hebat bagi sistem keuangan.

Kemudian penelitian yang dilakukan oleh Setiawan dan Bagaskara (2016) menggunakan data panel meneliti tentang hubungan antara NPF dan efisiensi biaya bank syariah di Indonesia. Menggunakan metode DEA (Data Envelopment Analysis) untuk efisiensi biaya dan menggunakan VAR (Vector Auto Regression) hubungan antara NPF dan efisiensi biaya. Hasil penelitiannya Bank Victoria Syariah (BVS) pada periode penelitian sebagai bank yang biayanya paling efisien. Efisiensi 
biaya rata-rata bank umum syariah adalah 0,937 atau $93,7 \%$, hal ini juga menunjukkan bahwa bank syariah masih tidak efisien dalam mengelola biaya mendukung hipotesis bahwa bank syariah memiliki manajemen yang buruk. Temuan mengungkapkan bahwa tingkat pertumbuhan PDB, Inflasi dan Capital Adequacy Ratio (CAR) memiliki efek negatif dan signifikan terhadap NPF, sementara nilai tukar dan Operational Efficiency Ratio (OER) memiliki pengaruh positif dan signifikan terhadap NPF. Di sisi lain, Financing to Deposit Ratio (FDR) tidak memiliki pengaruh signifikan terhadap NPF.

Kemudian penelitian yang dilakukan oleh Wahyuni (2014) tentang faktor-faktor yang mempengaruhi NPF. Penelitian ini menggunakan metode regresi linier berganda, hasilnya menunjukkan bahwa variabel Bank Indonesia Sertifikat Syariah (SBIS) berpengaruh positif dan signifikan terhadap Non-Performing Financing (NPF), dan variabel Capital Adequacy Ratio (CAR) berpengaruh negatif signifikan pada Non-Performing Financing (NPF). Sementara variabel Produk Domestik Bruto (PDB), inflasi, dan Financing Deposit Ratio (FDR) tidak signifikan mempengaruhi Non Performing Financing (NPF).

Padmantyo dan Muqorobin (2011) meneliti juga tentang variabel yang mempengaruhi kredit macet. Dengan pengujian Ordinary Least Square (OLS) memperoleh hasil menunjukkan bahwa jumlah pendanaan Bank Islam (FDR) dan tingkat PDB mempengaruhi tingkat pendanaan bermasalah (NPF) secara signifikan. Sedang di sisi lain, tingkat kredit macet perbankan konvensional dipengaruhi oleh tingkat suku bunga secara positif dan rasio kredit atas deposit (LDR) secara negatif. Berbagai temuan ini semakin menambah bukti bagaimana sistem ekonomi Islam dan perbankan Islam dapat mengurangi dampak krisis keuangan global secara signifikan bagi masyarakat domestik suatu negara. Pembiayaan bagi hasil merupakan pembiayaan yang tinggi tingkat risikonya 
dibandingkan dengan pembiayaan dengan sistem jual beli. Oleh karena itu, dapat diperkirakan bahwa bank Islam yang memiliki sikap terhadap risiko lebih tinggi akan memiliki pembiayaaan bagi hasil lebih tinggi pula (Yudha Trishananto, 2016:101).

Holmstrom (2008) dalam penelitiannya membuat formulasi untuk menghitung besaran moral hazard mendapatkan penemuan bahwa untuk meminimalisir sikap moral hazard perlu menciptakan sistem informasi tambahan misalnya pada akuntansi biaya dengan menggunakan informasi keagenan, perkiraan kondisi lingkungan dan disesuaikan dengan kontrak umum. Poetry dan Sanrego (2011) menggunakan metode VAR untuk meneliti tentang faktor mikro dan makro yang mempengaruhi NPF mendapatkan hasil bahwa dalam jangka pendek, tidak ada variabel yang signifikan mempengaruhi NPL dan NPF. Dalam jangka panjang variabel yang signifikan mempengaruhi NPL adalah nilai tukar, IPI, inflasi, SBI, LDR, dan CAR dan variabel yang signifikan mempengaruhi NPF adalah lnER, lnIPI, Inflasi, SBIS, FDR_BS, dan CAR. Penelitian ini menemukan bahwa NPF perbankan syariah lebih stabil dari NPL di perbankan konvensional untuk menangani fluktuasi variabel makro dan mikro.

Penelitian dengan metode deskriptif analitis tentang moral hazard juga dilakukan oleh Ibrahim dan Ragimun (2010) menyebutkan bahwa moral hazard merupakan insentif yang memiliki agenda dan tersembunyi berlawanan dengan etika hukum. Moral hazard terjadi karena regulasi yang lemah, penjaminan simpanan, penjaminan kredit, struktur kepemilikan yang terkonsentrasi, dan lemahnya disiplin pasar. Meskipun dalam periode penelitian, kinerja pembiayaan meningkat dan memiliki indikator FDR yang tinggi, tetapi besaran pembiayaan masih sangat kecil jika dibandingkan dengan kredit yang diberikan bank umum konvensional. Besaran pembiayaan hanya sekitar 3-5\% dari besaran 
kredit. Hal ini menunjukkan bahwa pangsa pembiayaan perbankan syariah masih sangat kecil jika dibandingkan dengan pangsa kredit bank umum konvensional (Fauziyah Adzimatinur dkk, 2015:107).

\section{METHODS}

Berdasarkan tingkat eksplansinya, penelitian ini termasuk dalam penelitian multivarian, yaitu penelitian yang menggunakan lebih dari satu variabel (J Supranto, 2003). Selain multivarian, penelitian ini juga memiliki sifat kuantitatif, yaitu mempunyai karakteristik menggunakan data yang berupa angka-angka, berorientasi melihat hubungan variabel yang diteliti, menguji teori, dan mencari generalisasi yang bernilai prediktif (Idrus, 2009).

Penelitian ini menggunakan data sekunder, yaitu data yang diperoleh melalui sumber kedua, biasanya data ini sudah siap pakai dan dipubllikasikan untuk diketahui masyarakat (Widarjono, 2009). Dalam penilitian ini menggunakan data sekunder yang bersumber dari: Statistik Perbankan Syariah yang dipublikasi oleh OJK dan Bank Indonesia dan Badan Pusat Statistik (BPS). Teknik pengumpulan data dalam penelitian ini menggunakan metode dokumentasi. Metode dokumentasi menurut (Arhami, 2005) adalah metode yang digunakan untuk mengumpulkan data berupa data-data tertulis yang mengandung keterangan dan penjelasan serta pemikiran tentang fenomena yang masih actual sesuai dengan masalah penelitian. Metode analisis data yang digunakan adalah metode koreksi kesalahan atau dikenal dengan nama error correction model (ECM). 


\section{RESULT AND DISCUSSION}

Penelitian ini menggunakan uji pengaruh jangka pendek dan jangka panjang dengan menggunakan metode ECM, berikut hasil uji model jangka pendek dan hasil uji model jangka panjang:

Tabel .1.

Hasil Uji Model Jangka Pendek

\begin{tabular}{|c|c|c|}
\hline \multicolumn{3}{|c|}{ Uji Model Jangka Pendek } \\
\hline Variabel & Koefisien & Prob \\
\hline $\mathrm{C}$ & $-0,006608$ & 0,8336 \\
\hline dLogGDP & $-0,08888$ & 0,9244 \\
\hline dINF & $-0,00887$ & 0,8459 \\
\hline dRR & 0,033876 & 0,7289 \\
\hline dRAP & $-2,508137$ & 0,0219 \\
\hline dFDR & 0,044843 & 0,0031 \\
\hline ECT(-1) & $-0,239322$ & 0,0193 \\
\hline \multicolumn{2}{|l|}{ R-squared } & 0,20595 \\
\hline \multicolumn{2}{|l|}{ Prob(F-statistic) } & 0,01871 \\
\hline
\end{tabular}

Dari hasil pengujian di atas maka diperoleh persamaan jangka pendek pada penelitian ini, sebagai berikut:

Dan berikut tabel hasil uji model jangka panjang, sebagai berikut:

Tabel .2.

Hasil Model Jangka Panjang

\begin{tabular}{|c|c|c|}
\hline \multicolumn{3}{|c|}{ Uji Model Jangka Panjang } \\
\hline Variabel & Koefisien & Prob \\
\hline $\mathrm{C}$ & $-8,414302$ & 0,0057 \\
\hline LogGDP & 2,889727 & 0,0000 \\
\hline INF & $-0,053348$ & 0,1136 \\
\hline RR & $-0,062841$ & 0,6450 \\
\hline RAP & $-3,391194$ & 0,0000 \\
\hline FDR & 0,051955 & 0,0003 \\
\hline \multicolumn{2}{|l|}{ R-squared } & 0,72754 \\
\hline \multicolumn{2}{|l|}{ Prob(F-statistic) } & 0,00000 \\
\hline
\end{tabular}


Dari hasil pengujian di atas maka diperoleh persamaan jangka panjang pada penelitian ini, sebagai berikut:

$\mathrm{NPF}=-8,414302+2,889727 \operatorname{LogGDP}-0,053348 \mathrm{INF}-0,062841 \mathrm{RR}-$ 3,391194RAP + 0,051955FDR

Berdasarkan analisis data di atas didapatkan hasil untuk mengetahui adanya indikasi moral hazard pada penelitian ini dengan melihat uji hipotesis dan arah dari tiap variabel. Hasil dari olah data tersebut dapat dirangkum dalam tabel di bawah ini:

\section{Tabel .3.}

\section{Moral hazard di Perbankan Syariah}

\begin{tabular}{|c|c|c|c|}
\hline Variabel & Signifikansi & Arah & Indikasi \\
\hline \multicolumn{4}{|l|}{ Jangka Pendek } \\
\hline $\mathrm{D}(\mathrm{LOG}(\mathrm{GDP}))$ & $\begin{array}{l}\text { Tidak } \\
\text { Signifikan }\end{array}$ & $(-)$ & Tidak Berpengaruh \\
\hline $\mathrm{D}(\mathrm{INF})$ & $\begin{array}{l}\text { Tidak } \\
\text { Signifikan }\end{array}$ & $(-)$ & Tidak Berpengaruh \\
\hline $\mathrm{D}(\mathrm{RR})$ & $\begin{array}{l}\text { Tidak } \\
\text { Signifikan }\end{array}$ & $(+)$ & Tidak Berpengaruh \\
\hline $\mathrm{D}(\mathrm{RAP})$ & Signifikan & $(-)$ & Tidak Terdapat Indikasi Moral Hazard \\
\hline $\mathrm{D}(\mathrm{FDR})$ & Signifikan & $(+)$ & Tidak Terdapat Indikasi Moral Hazard \\
\hline \multicolumn{4}{|l|}{ Jangka Panjang } \\
\hline LOG(GDP) & Signifikan & $(+)$ & Terdapat Indikasi Moral Hazard \\
\hline INF & $\begin{array}{l}\text { Tidak } \\
\text { Signifikan }\end{array}$ & $(-)$ & Tidak Berpengaruh \\
\hline RR & $\begin{array}{l}\text { Tidak } \\
\text { Signifikan }\end{array}$ & $(-)$ & Tidak Berpengaruh \\
\hline RAP & Signifikan & $(-)$ & Tidak Terdapat Indikasi Moral Hazard \\
\hline FDR & Signifikan & $(+)$ & Tidak Terdapat Indikasi Moral Hazard \\
\hline
\end{tabular}

Dari pengujian jangka pendek GDP dengan probabilitas sebesar 0.9244 tidak berpengaruh terhadap NPF, namun dalam jangka panjang GDP berpengaruh positif signifikan terhadap NPF dengan probabilitas sebesar 0.0000. Hal ini berarti dalam jangka panjang setiap kenaikan GDP sebesar satu persen mempengaruhi kenaikan NPF sebesar 2,88 persen. Selain interpretasi tersebut dari arah hasil pengujian hipotesis terdapat 
indikasi moral hazard yang ditunjukkan dari arah pengaruh positif variabel GDP terhadap NPF.

Kondisi dunia bisnis yang sedang mengalami kemajuan merupakan bentuk dari kondisi ekonomi sedang meningkat. Kemajuan dunia bisnis pada saat sektor ekonomi meningkat ini ditunjukkan dengan kenaikan GDP. Dalam keadaan dunia bisnis yang mengalami kemajuan dan kondisi ekonomi sedang meningkat seharusnya kredit macet akan berkurang. Namun jika pada kondisi ekonomi sedang naik dengan ditandainya GDP yang meningkat, kemudian di sektor perbankan syariah NPF juga ikut mengalami kenaikan, maka di situ terjadi indikasi adanya moral hazard yang terjadi di perbankan syariah.

Hasil penelitian ini sejalan dengan penelitian yang dilakukan oleh Anto dan Setyowati (2008) bahwa GDP tidak mempengaruhi NPF dalam jangka pendek namun memberikan pengaruh dalam jangka panjang. $\mathrm{Wu}$, Chang, dan Zekiye (2003) juga menemukan bahwa kondisi makro ekonomi yang direpresentasikan dengan GDP dan kondisi pasar real estate signifikan terhadap NPF. Mereka juga menyebutkan bahwa berarti bank tidak cukup hati-hati dalam menyalurkan kredit. Dari hasil pengujian pada penelitian ini dan didukung dengan penelitian terdahulu memberikan indikasi bahwa bank syariah masih kurang berhati-hati dalam penyalurkan dananya, terlebih untuk pembiayaan dalam jangka panjang yang memberikan efek risiko yang lebih besar.

Pengujian hipotesis variabel RR (Rasio Margin Murabahah terhadap Bagi Hasil Mudharabah Musyarakah) menunjukkan probabilitas sebesar 0,7289 untuk jangka pendek dan 0,6450 untuk jangka panjang lebih besar dari $a=0,05$, yaitu variabel $R R$ tidak berpengaruh terhadap NPF. Hal ini berarti bahwa berapapun kenaikan atau penurunan variabel RR tidak akan berpengaruh terhadap NPF. Return yang diberikan bank syariah kepada nasabah disesuikan dengan risiko yang dihadapinya. Pada 
kasus ini return yang diberikan bank syariah tidak begitu mempengaruhi tingkat NPF sebagai indikator adanya moral hazard diperbankan syariah dimungkinkan karena bank syariah akan sangat berhati-hati memberikan return karena penetapan return bank syariah pun masih mengacu pada return yang ditetapkan Bank Indonesia sebagai bank sentral. Selain antisipasi yang dilakukan bank syariah dengan menetapkan return yang sesuai risiko juga sangat baik, dengan adanya suku bunga acuan pada bank sentral ini akan berdampak pada pembagian return yang tidak serta merta bisa diterapkan oleh bank syariah tanpa keikutsertaan bank sentral dalam mengantisipasi kemungkinan buruk yang timbul dari pemberian return bank syariah kepada nasabah. Walaupun bank syariah pada dasarnya memang mengacu pada prinsip-prinsip Islam namun pada faktanya di Indonesia pertumbuhannya juga masih sangat kecil dibanding bank konvensional yaitu kurang lebih 5\% (Outlook OJK:2016), dan masih bergantung pada regulasi pada Bank Indonesia sebagai pemegang otorisasi perbankan di Indonesia.

Pada hasil pengujian untuk variabel RAP diatas menunjukkan probabilitas jangka pendek dan jangka panjang sebesar 0,0219 dan 0,0000, dengan koefisien sebesar -2,508 dan -3,391. Keduanya berarti variabel RAP berpengaruh negatif terhadap NPF, dimana pada jangka pendek setiap kenaikan 1 persen variabel RAP berpengaruh menurunkan NPF sebesar 2,50 persen, dan dalam jangka panjang setiap kenaikan RAP 1 persen menurunkan pula NPF sebesar 3,39 persen. Dan dari arah hasil pengujian diperoleh arah yang sama dengan hipotesis yaitu negatif, hal itu berarti tidak ada indikasi moral hazard di perbankan syariah dengan ditunjukkan melalui hubungan variabel RAP dan NPF ini.

Penyusunan sistem kontrak yang lebih optimal mendorong bank syariah cenderung memilih pembiayaan dengan skim murabahah agar lebih terhindar dari risiko-risiko yang dapat muncul dikemudian hari 
daripada pembiayaan skim bagi hasil seperti mudharabah musyarakah. Namun, skema pembiayaan murabahah sendiri sebetulnya juga akan menimbulkan lambatnya pertumbuhan bank syariah dari segi sektor produktif yang cenderung dapat menghasilkan benefit yang besar lewat laju pembiayaan yang diberikan, dan juga dengan penyaluran dana pada sektor produktif ini tentunya bank syariah lebih dapat mengaplikasikan pesan moral Islam yang dibawa perbankan syariah dalam menjalankan sistem operasionalnya.

Financing to Depocit Ratio sebagai variabel untuk mengetahui sejauh mana pembiayaan yang disalurkan oleh bank syariah kepada sektor riil dari dana pihak ketiga yang telah dihimpun dapat juga menjadi variabel indikator ada atau tidaknya sebuah bank syariah terjadi indikasi moral hazard. Dan dari pengujian pada penelitian ini menunjukkan dalam jangka pendek maupun jangka panjang FDR berpengaruh terhadap NPF dengan probabilitas sebesar 0,0031 dan 0,0003 lebih kecil dari a $=5 \%$, dengan koefisien masing-masing adalah 0,044 dan 0,051, artinya dalam jangka pendek setiap kenaikan FDR 1 persen menaikkan pula tingkat NPF sebesar 0,044 persen, dan dalam jangka panjang setiap kenaikan FDR 1 persen menaikkan pula tingkat NPF sebesar 0,052 persen. Dalam hubungan FDR dengan NPF diketahui bahwa tidak ada indikasi moral hazard yang terjadi di perbankan syariah.

Rasio finance to deposit ratio (FDR) dipergunakan untuk mengukur sejauh mana dana pinjaman yang berhasil dikerahkan oleh bank kepada nasabah peminjam yang bersumber dari dana pihak ketiga. Tinggi rendahnya rasio ini menunjukkan tingkat likuiditas bank tersebut. Sehingga semakin tinggi angka Finance To Deposit Ratio (FDR) suatu bank, berarti digambarkan sebagai bank yang kurang likuid dibanding dengan bank yang nilai Finance To Deposit Ratio (FDR) lebih kecil. 
Menurut Mulyono (1995), rasio FDR merupakan rasio perbandingan antara jumlah dana yang disalurkan ke masyarakat (kredit) dengan jumlah dana masyarakat dan modal sendiri yang digunakan. Semakin tinggi rasio ini semakin rendah pula kemampuan likuiditas bank (Dendawijaya, 2001). Bila FDR dilakukan secara masif bisa mengakibatkan meningkatnya risiko kredit macet, tetapi bila tingkat FDR rendah maka sektor riil juga tidak akan berkembang. Perbandingan kedua rasio ini dapat tercermin melalui kenaikan atau penurunan rasio antara FDR dan NPF di bawah ini. Dimana fluktuasi rasio FDR diikuti pula dengan fluktuasi persentase NPF perbankan syariah.

Operasional yang dijalankan oleh bank syariah tidak menunjukkan adanya indikasi moral hazard seperti penelitian yang dilakukan oleh Padmantyo dan Agus (2011) bahwa jumlah pendanaan Bank Islam (FDR) mempengaruhi tingkat pendanaan bermasalah (NPF). Oleh karena itu, kedua variabel ini memang berbanding lurus antara kenaikan/penurunan FDR akan menaikkan atau menurunkan rasio dari NPF. Peningkatan FDR juga akan meningkatkan kredit macet begitu pula sebaliknya. Pengaruh hipotesis dengan arah positif berlaku pada kedua variabel ini

Bank merupakan agent of development yang bertugas sebagai lembaga keuangan yang memobilisasi dana guna pembangunan ekonomi, dan hal tersebut tidak lepas dari fungsi bank sebagai lembaga intermediasi. Perbankan berperan dalam mempermudah proses pengalihan dana dari pihak yang kelebihan dana pada pihak yang membutuhkan dana, untuk melakukan proses tersebut (Andri Veno, 2016:24). Dendawijaya (2009) mengatakan bahwa bank adalah suatu badan usaha yang tugas utamanya sebagai lembaga perantara keuangan yang menyalurkan dana dari pihak yang kelebihan dana (idle fund surplus) kepada pihak yang membutuhkan dana atau kekurangan dana (deficit unit) pada waktu yang ditentukan. 
Fungsi intermediasi suatu bank diukur dalam rasio, yaitu Financing to Deposit Ratio (FDR) pada bank syariah.

Dengan melihat risiko yang timbul dari kegiatan penyaluran dana perbankan syariah yaitu meningkatnya NPF seiring dengan meningkatnya FDR, hal ini lebih dimaknai sebagai suatu konsekuensi dari adanya kegiatan pendistribusian dana. Bahwa pendistribusian dana yang dihimpun bank syariah juga akan diikuti oleh pendistribusian bagi hasil. Bagi hasil dalam konteks perbankan syariah sendiri memiliki makna bahwa kedua belah pihak berbagi risiko untung maupun rugi.

\section{CONCLUSION}

Penelitian ini bertujuan untuk mengetahui indikasi moral hazard yang terdapat di perbankan syariah melalui indikator internal maupun eksternal perbankan syariah. Hasil dari penelitian ini mengkonfirmasi penemuan-penemuan sebelumnya bahwa dalam jangka panjang ketika kondisi perekonomian yang meningkat dapat dilihat dari peningkatan GDP kemudian di sektor perbankan syariah NPF juga ikut mengalami kenaikan, maka di situ terjadi indikasi adanya moral hazard yang terjadi di perbankan syariah.

Namun, ketika menghadapi naik turunnya inflasi bank syariah tidak begitu terpengaruh sebab instrumen yang digunakan memiliki skim pembagian profit dan risk yang disesuaikan dengan persentase kontrak yang telah disepakati di awal. Sehingga ketika terjadi kendala baik kendala yang berasal dari turunnya pendapatan usaha maupun kendala yang diakibatkan kondisi sosial ekonomi, bank dan nasabah akan menggunakan sistem kongsi untuk menanggung keuntungan atau kerugian bersama. Stabilitas perbankan syariah tidak mudah dipengaruhi oleh kenaikan maupun penurunan inflasi dikarenakan sistem perbankan 
syariah memakai sistem profit loss sharing, dan tidak semata-mata menggunakan suku bunga Bank Indonesia sebagai acuan.

Rasio-rasio keuangan berfungsi menunjukan kinerja perbankan syariah yang sesungguhnya, diantaranya kinerja intermediasi berupa penghimpunan dana tabungan, giro, deposito, dan penyaluran dana pada pembiayaan (Allselia Riski Azhari \& Rofiul Wahyudi, 2020:97). Pada indikator internal perbankan syariah yaitu Rasio Return, Rasio Pembiayaan, dan FDR dapat diketahui bahwa tidak menunjukkan adanya indikasi moral hazard. Dimana pada Rasio Return yang tidak memiliki pengaruh terhadap adanya indikasi moral hazard, mencerminkan sikap bank syariah yang begitu hati-hati dalam memberikan return, hal ini sebagai bentuk antisipasi yang sangat baik dengan menetapkan return yang sesuai dengan risiko. Selain itu, penetapan return bank syariah yang masih mengacu pada return yang ditetapkan Bank Indonesia sebagai bank sentral akan berdampak pada pembagian return yang tidak serta merta bisa diterapkan oleh bank syariah tanpa keikutsertaan bank sentral dalam mengantisipasi kemungkinan buruk yang timbul dari pemberian return bank syariah kepada nasabah.

Sikap prudential banking sangat terlihat pada internal institusi perbankan syariah berkaitan dengan pengelolaan dana, khususnya pada manajeman pembiayaannya. Sebagai bank yang berlandaskan prinsip Islam tentu bank syariah tidak hanya institusi yang berorientasi pada profit duniawi semata namun mampu membawa pesan dan peran moral nilai Islam disamping ikut membangun ekonomi Indonesia.Untuk itu perlu adanya penjaminan nasional serta sistem hukum yang memadai bagi perbankan syariah. 


\section{IMPLIKASI}

Implikasi penelitian yaitu untuk menambah khasanah ilmu pengetahuan berkaitan dengan indikasi moral hazard yang bisa terjadi ketika adanya kinerja pembiayaan perbankan syariah yang buruk.

\section{REFERENCES}

Adiwarman. (2004). BI Intensifkan Pengawasan terhadap Perbankan Syariah. Kompas. Internet.

Anto dan Setyowati. (2007). Indikasi Moral Hazard dalam Penyaluran Dana Pihak Ketiga: (Studi Komparatif Bank Umum Konvensional dan Bank Umum Syariah Tahun 2003:1- 2007). Dalam Current Issues Lembaga Keuangan Syariah. Jakarta: Kencana Prenada.

Arikunto, Syharsimi. (2006). Prosedur Penelitian Suatu Pendekatan Praktik Edisi Revisi VI. Jakarta: Rineka Cipta.

Arhami, Muhammad. (2005). Konsep Sistem Pakar. Yogyakarta: Andi Offset.

Arijanto, Agus. (2010). Dosa-Dosa Orang Tua Tehadap Anak dalam Hal Finansial. Jakarta: PT Elex Media Komputindo Kelompok Gramedia.

Case dan Fair. (2007). Prinsip-prinsip Ekonomi. Jakarta: Erlangga

Covitz dan Heitfield. (1999). Monitoring, Moral Hazard, and Market Power: a Model of Bank Lending. Federal Depocit Insurance Corporation.

Dendawijaya, Lukman. 2001. Manajemen Perbankan. Jakarta: PT Gramedia Pustaka Utama. Dow, James. (2000). What is Systemic Risk?Moral Hazard, Initial Shocks and Propagation. IMES Discussion Paper Series 2000-E-17.

D. Nachrowi, Nachrowi dan Usman. (2002). Penggunaan Teknik Ekonometri.

Jakarta: Raja Grafindo Persada. 
Dreher, Axel. (2004). Does the IMF cause Moral Hazard? A Critical Review of the Evidence. Internet.

Gujarati, Damodar. (2004). Ekonometrika Dasar. Jakarta: Erlangga.Hakim, Maskanul C. (2011). Belajar Mudah Ekonomi Islam. Banten: Shuhuf Media Insani. Holmstrom, B. (2008). Moral Hazard and Observability. The Bell Journal of Economics, Vol.10,No.1.

Idrus, Muhammad. (2009). Metode Penelitian Ilmu Sosial, Pendekatan Kualitatif dan Kuantitatif. Jakarta: Erlangga.

Ikatan Ahli Ekonomi Islam (IAEI). (2009). Current Issues Lembaga Keuangan Syariah. Jakarta: Kencana Prenada.

Insukindro. (2001). Ekonomi Uang dan Bank. Yogyakarta: BPFE UGM.

Ismal, Rifki. (2006). Assessing Moral Hazard Problem in Murabahah Financing. Journal of Islamic Economics, Banking and Finance, Volume-5 Number-2.

Kasmir. (2005). Bank dan Lembaga Keuangan Lain. Jakarta: PT. Raja Grafindo Persada.

Krugman, P. (1999). What happened to Asia?, Conference paper in Japan. South Western Publishing.

Luiz, Silva dan Masaru. (2001). Can "Moral Hazard" Explain the Asians Crises?. Tokyo: ADB Institute

Mankiw, N. G. (2007). Makroekonomi. Jakarta: Erlangga.

Mishkin, S. Frederic. (2001). Prudential Supervision Whal Works and What Doesn't, NBER Conference Report. Chicago: The University of

Chicago Press

Misra dan Dhal. (2009). Pro-cyclical Management of Banks' NonPerforming Loans by the Indian Public Sector Banks. Internet.

Muhammad. (2004). Managemen Dana Bank Syariah. Yogyakarta: Ekonisia. Edisi Pertama. 
Muljawan, Dadang. (2001). Perbankan Syariah: Filosofi Operasi. Biro Perbankan Syariah, Bank Indonesia.

Morris, Golstein. (1998). The Asian Financial Crisis, Policy Brief 98-1. Institute for International Economics. Internet.

Nasution, Mustafa Edwin dan Ranti Wiliasih. (2007). Profit Sharing dan Moral Hazard dalam Penyaluran Dana Pihak Ketiga Bank Umum Syariah Di Indonesia". Jurnal Ekonomi dan Pembangunan Indonesia Vol. VII No. 02.

Padmantyo dan Agus. (2014). Analisis Variabel Yang Mempengaruhi Kredit Macet Perbankan di Indonesia. Laporan Penelitian Insentif Regular Kompetitif UMS.

Padmantyo dan Sanrego. (2008). Pengaruh Variabel Makro dan Mikro terhadap NPL Perbankan Konvensional dan NPF Perbankan Syariah. Islamic Finance \& Business Review,Vol. $6 \quad$ No.2.

Perbankan Syariah: Lebih Tahan Krisis Global. Artikel Bank Indonesia. www.bi.go.id

Prihatiningsih. (2012). Dinamika FDR Perbankan Syariah Tahun 20062011. Jurnal Orbith, Vol. 8 No. 3.

Wahyuni, Sri. (2014). Faktor-faktor yang Mempengaruhi Non Performing Financing (NPF) pada Bank Umum Syariah. Jurnal Tekun Volume V, No. 02.

Siringoringo, Renniwaty. (2012). Karakteristik dan Fungsi Intermediasi Perbankan di Indonesia. Buletin Ekonomi Moneter dan Perbankan.

Scott, William R. (2000). Financial Accounting Theory. Second edition. Canada: Prentice Hall

Sugiyono. (2008). Metode Penelitian Bisnis. Bandung: CV. Alvabeta Supranto, J. (2003). Metode Riset dan Aplikasinya dalam Pemasaran. Jakarta: Rineka Cipta. 
Setiawan dan Bagaskara. (2016). Non-Performing Financing (NPF) and Cost Efficiency of Islamic Banks in Indonesia Period 2012Q1 to 2015Q2. Sixth Asia-Pacific Conference on Global Business, Economics, Finance and Social Sciences (AP16Thai Conference).

Rodoni, Ahmad dan Abdul Hamid. (2008). Lembaga Keuangan. Jakarta: Zikrul Hakim .

Widarjono, Agus. (2009). Ekonometrika : Pengantar dan Aplikasinya (Dilengkapi dengan Aplikasi EViews). Yogyakarta: Ekonisia.

Williamson, SD. (1987). Recent Development in Modelling Financial Intermediation, in Lewis K., Mervyn dan Latifa M. Algaoud. (2001). Islamic Banking. Cheltenham. UK: Edward Elgar.

Wu, chang, dkk. (2003). Banking System, Real Estate Markets, And Non Performing Loans. International Real Estate Review Vol. 6 No. 1.

Yasin, Ach. (2014). Analisis Faktor-faktor yang Mempengaruhi Non Performing Financing (NPF) di Industri bank Pembiayaan Rakyat (BPR) Syariah di Indonesia. Akrual Jurnal Akuntansi 5 183-203.

Outlook OJK 2016

Surat Edaran Bank Indonesia No. 26/5/BPPP tanggal 2 Mei 1993

Statistik Perbankan Syariah, www.bi.go.id

Statistik Perbankan Syariah, www.ojk.go.id

Www.bps.go.id

Www.Ekonomisyariah.Org. OJK Targetkan Jakarta Jadi Pusat Keuangan Syariah. Akses 30 Desember 2016.

Sekilas Perbankan Syariah di Indonesia. Diambil tanggal 24 Februari 2017 dari www.bi.go.id/id/perbankan/syariah/contents/default.aspx.

Khasanah, A. N. (2016). Pengaruh Intellectual Capital dan Islamicity Performance Index Terhadap Kinerja Keuangan Perbankan Syariah di Indonesia. Jurnal Nominal, 5(1). 
Jahja, A. S. (2012). Analisis Perbandingan kinerja keuangan perbankan Syariah dengan perbankan Konvensional. Epistemé: Jurnal Pengembangan Ilmu Keislaman, 7(2).

Pangesti, K. P., \& Sutanto, H. A. (2020). Determinan Kinerja Keuangan Perbankan Syariah Periode 2014-2018. ECONBANK: Journal of Economics and Banking, 2(1)

Saekhu, S. (2015). Pengaruh Inflasi Terhadap Kinerja Pembiayaan Bank Syariah, Volume Pasar Uang Antar Bank Syariah, Dan Posisi Outstanding Sertifikat Wadiah Bank Indonesia. Economica: Jurnal Ekonomi Islam, 6(1).

Trishananto, Y. (2016). Sistem Pengukuran Kinerja dan Kinerja Pembiayaan bagi Hasil Perbankan Syariah di Indonesia. Muqtasid: Jurnal Ekonomi dan Perbankan Syariah, 7(2).

Azhari, A. R., \& Wahyudi, R. (2020). Analisis kinerja perbankan syariah di Indonesia: Studi masa pandemi Covid-19. JESI (Jurnal Ekonomi Syariah Indonesia), 10(2).

Veno, A., \& Syamsudin, S. (2016). Analisis Trend Kinerja Keuangan Perbankan Syariah Tahun 2015 Sampai Dengan 2017. BISNIS: Jurnal Bisnis dan Manajemen Islam, 4(1).

Rizal, M., Mustapita, A. F., \& Sari, A. F. K. (2020). Pelatihan Untuk Pengajuan Pembiayaan Mudharabah Perbankan Syariah Sebagai Peningkatan Kinerja Umkm. Jurnal Inovasi Hasil Pengabdian Masyarakat, 3(1).

Azis, M. T. (2018). Analisa Kinerja Perbankan Syariah Indonesia Ditinjau Dari Maqasyid Syariah. Al-Amwal, 10(1).

Munir, A. S. (2017). Analisis Faktor-Faktor Yang Mempengaruhi Kinerja Keuangan Perbankan Syariah di Indonesia. Jurnal Ummul Qura, $9(1)$. 
Permatasari, D., \& Yulianto, A. R. (2018). Analisis Kinerja Keuangan : Kemampuan Bank Syariah Dalam Penyaluran Pembiayaan. Jurnal Akuntansi Indonesia, 7(1).

Adzimatinur, F., Hartoyo, S., \& Wiliasih, R. (2015). Faktor-faktor yang memengaruhi besaran pembiayaan perbankan syariah di Indonesia. Al-Muzara'ah, 3(2).

Kasmiarno, K. S., \& Mintaroem, K. (2016). Analisis Pengaruh Indikator Ekonomi dan Kinerja Perbankan Syariah Terhadap Penyerapan Tenaga Kerja Pada Perbankan Syariah di Indonesia Tahun 20082014. Jurnal Ekonomi Syariah Teori dan Terapan, 3(10).

Quatro, C., Asnaini, A., \& Oktarina, A. (2021). Pengaruh Volume Pembiayaan Bagi Hasil Dan Pembiayaan Murabahah Terhadap Kinerja Keuangan Bank Umum Syariah Periode 2015-2020. Al-Intaj: Jurnal Ekonomi dan Perbankan Syariah, 7(1).

Wahyuni, M. (2016). Pengaruh Volume Pembiayaan Bagi Hasil dan Pembiayaan Murabahah terhadap Kinerja Keuangan Bank Umum Syariah dengan NPF sebagai Variabel Moderasi. EBBANK, 7(1).

Iqbal, M. (2017). Perbandingan Pengelolaan Risiko Kredit Perbankan Syariah dan Perbankan Konvensional. Jurnal Keuangan dan Perbankan, 21(3).

Sagantha, F. (2020). Meninjau Kinerja Bank Syariah di Indonesia. Scientific Journal Of Reflection: Economic, Accounting, Management And Business, 3(1).

Ardana, Y., \& Wulandari, W. (2018). Tingkat Suku Bunga, Kinerja Keuangan dan Tingkat Bagi Hasil Deposito Pada Perbankan Syariah. Esensi: Jurnal Bisnis dan Manajemen, 8(2).

Pratikto, H., \& Sugianto, I. (2017). Kinerja Efisiensi Bank Syariah Sebelum dan Sesudah Krisis Global Berdasarkan Data Envelopment Analysis. Jurnal Ekonomi Bisnis, 16(2). 
Luthan, E., Rizki, S. A., \& Edmawati, S. D. (2017). Pengaruh Pengungkapan Tanggung Jawab Sosial Perusahaan Terhadap Kinerja Keuangan. EKUITAS (Jurnal Ekonomi dan Bisnis), 1(2). 